\title{
Pengembangan Website Cybercounseling Realita untuk Meningkatkan Keterbukaan Diri Siswa Sekolah Menengah Kejuruan
}

\author{
Abi Fa'izzarahman Prabawa', M. Ramli ${ }^{2}$, Lutfi Fauzan ${ }^{2}$ \\ ${ }^{1}$ Sekolah Menengah Atas Islam Sabilillah Malang, \\ Jl. Ikan Kakap No. 1 B, Malang, Jawa Timur, Indonesia 65142 \\ ${ }^{2}$ Jurusan Bimbingan dan Konseling, Fakultas Ilmu Pendidikan, Universitas Negeri Malang, \\ Jl. Semarang No. 5, Malang, Jawa Timur, Indonesia 65145 \\ E-mail: abibkum@gmail.com
}

Artikel diterima: 13 Mei 2017; direvisi 19 Maret 2018; disetujui 17 April 2018

\begin{abstract}
This research and development aims to produce a cybercounseling reality website and a reality cybercounseling guidebook to improve self-disclosure for Vocational High School students which are grateful theoretically and practically. The research and development study steps are: preliminary study, product development, and product test. Product's guidelines are tested using one group pretest-posttest design. Product test results show that cybercounseling reality website is gratefully theoretically and practically and also effectively to improve Vocational High School students' self-disclosure.
\end{abstract}

Keywords: cybercounseling; reality therapy; self-disclosure; research and development

\begin{abstract}
Abstrak: Penelitian dan pengembangan ini bertujuan menghasilkan website dan panduan cybercounseling realita untuk meningkatkan keterbukaan diri siswa Sekolah Menengah Kejuruan (SMK) yang berterima secara teoretis dan praktis. Rancangan penelitian ini menggunakan penelitian dan pengembangan dengan langkah: studi pendahuluan, pengembangan produk, dan uji produk. Panduan penggunaan produk diuji menggunakan one group pretest-posttest design. Hasil uji produk menunjukkan bahwa website cybercounseling realita berterima secara teoretis dan praktis serta efektif untuk meningkatkan keterbukaan diri siswa SMK.
\end{abstract}

Kata kunci: cybercounseling; pendekatan realita; keterbukaan diri; penelitian dan pengembangan

Perkembangan kecanggihan teknologi berimbas pada kebiasaan dan gaya hidup manusia (Dewanti, Widada, \& Triyono, 2016; Grinter, Palen, \& Eldridge, 2006). Remaja saat ini lebih suka berbagi cerita dengan menggunakan media sosial - Facebook, BlackBerry Messenger, Whatsapp, dll. Ada berbagai berbagai dampak positif dan negatif ketika seseorang secara terbuka menceritakan diri di sosial media. Keterbukaan diri seseorang di media sosial salah satunya berdampak kecemasan psikologis. Kecemasan muncul akibat dari berbagai balikan negatif yang ditulis dengan bebas oleh pembaca (Amedie, 2015). Kendati demikian, para remaja modern saat ini tidak begitu mempersoalkan hal tersebut. Bagi mereka dengan bercerita melalui media sosial akan lebih banyak mendapat perhatian, dukungan dari banyak orang, dan respon yang cepat (Asandi \& Rosyidi, 2010). Rasional tersebut yang membuat remaja lebih senang berbicara secara terbuka melalui media online daripada bercerita secara langsung kepada orang lain. 
Keterbukaan diri dapat menjadikan remaja lebih adaptif, percaya diri, kompeten, dapat diandalkan, mampu bersikap positif, dan objektif (Gainau, 2009). Sebaliknya individu yang kurang mampu membuka diri, akan sulit menyesuaikan diri, kurang percaya diri, timbul perasaan takut, cemas, merasa rendah diri, dan tertutup. Seperti halnya dengan siswa kelas X SMK yang masuk pada fase remaja. Sebagai siswa dan warga sekolah baru, mereka diharapkan mampu membuka diri dengan baik agar mencapai perkembangan yang optimal. Mampu membuka diri terhadap lingkungan baru, mengungkapkan perasaan, mengungkapkan pendapat, dan bertukar pengalaman merupakan aspek penting keterbukaan diri dalam bersosial (Barak \& Gluck-Ofri, 2007).

Fakta menunjukkan $\pm 70 \%$ siswa SMK tertutup terhadap persoalannya, baik persoalan yang menyangkut pribadi, belajar, karier, maupun sosialnya (Pinarti, 2010). Kurangnya tingkat keterbukaan diri siswa juga ditemukan di SMK "X" Kota Malang. Kurangnya tingkat keterbukaan diri tersebut yakni ketika diskusi di dalam kelas, siswa enggan untuk berpendapat dan tidak mau mengungkapkan argumennya jika mereka tidak ditunjuk oleh guru.

Merujuk dari pengalaman di lapangan, maka penting bagi konselor untuk membantu siswa meningkatkan keterbukaan dirinya demi mencapai perkembangan yang optimal. Ada beberapa solusi yang pernah digunakan untuk membantu meningkatkan keterbukaan diri, baik melalui bimbingan ataupun konseling. Adapun bentuk solusi tersebut di antaranya: konseling kelompok person centered, homeroom, dan permainan simulasi (Andari, 2015; Jannah, Zen, \& Muslihati, 2016; Sastama, Muslim, \& Djannah, 2017). Aspek yang dikuatkan untuk meningkatkan keterbukaan diri yaitu: aspek keterampilan (behavior) melalui homeroom dan permainan simulasi serta aspek afeksi melalui konseling kelompok person centered. Beberapa solusi yang pernah digunakan, praktis tidak semua aspek individu - kognitif, afektif, dan behavioral tersentuh melalui intervensi yang diberikan.

Individu yang bertanggungjawab adalah individu yang dapat menyelaraskan antara keinginan, tujuan, kebutuhan dengan empat dimensi perilaku, yaitu: pikiran (kognitif), perasaan (afektif), tindakan (behavior), dan fisiologis (Burdenski Jr, 2011). Hal itu diibaratkan menjadi kesatuan komponen sebuah mobil. Pikiran dan tindakan adalah roda depan dan perasaan dan fisiologis adalah roda belakang. Layanan konseling yang dapat digunakan untuk menyelaraskan empat aspek tersebut yakni melalui konseling realita. Konseling realita ditawarkan karena konseling ini terbukti dapat meningkatkan penyesuaian diri siswa (Novalina, 2017). Aspek penting dalam penyesuaian diri siswa adalah keterbukaan diri (Katayama, 1996; Nehra \& Rangnekar, 2017; Swenson \& Rose, 2009). Maka demikian, diharapkan konseling realita efektif untuk meningkatkan keterbukaan diri.

Konseling Realita disebut juga dengan "teori pilihan" yang beranggapan bahwa setiap tingkah laku yang dilakukan oleh individu merupakan tingkah laku sesuai pilihannya. Pilihan-pilihan individu berasal dari dorongan pemenuhan lima kebutuhan genetik yang berasal dari internal individu bukan dari eksternal individu (Glasser, 1999). Lima kebutuhan dasar tersebut yaitu: bertahan hidup; mencinta dan dicintai; kesenangan; prestasi dan kekuasaan; serta kebebasan. Berdasarkan lima kebutuhan dasar manusia, rendahnya keterbukaan diri siswa berhubungan dengan kebutuhan akan kekuasaan dan prestasi. Pikiran takut salah, mendapat cemooh dari teman, dan respon negatif dari guru menyebabkan siswa tidak berani mengungkapkan pendapat. Melalui konseling realita, siswa dibantu untuk melatih kemampuan berpikir lebih positif-aspek kognitif, keterampilan menyampaikan pendapat—aspek behavior, mengenali perasaan yang mengikuti—aspek afektif, dan gejala fisik yang timbul-aspek fisiologis.

Seorang konselor yang harus selalu mengerahkan kemampuan akademiknya untuk melakukan layanan konseling (Radjah, 2016), perlu terus berinovasi. Salah satu terobosan baru dalam konseling adalah cybercounseling. Cybercounseling diberikan mengingat perbandingan jumlah konselor dan siswa yang tidak proporsional. Perbandingan jumlah yang tidak proporsional berpengaruh pada kualitas layanan yang diberikan kepada siswa. Jawa Timur masih kekurangan konselor sebanyak 12.556 personel pada masing-masing jenjang dari SD sampai SMK (Rachman, 2016). Konselor kesulitan untuk memberikan konseling secara merata dengan alasan keterbatasan waktu tatap muka. Dengan demikian perlu adanya terobosan yang memungkinkan layanan dapat diberikan di luar jam sekolah, yaitu cybercounseling. 
Cybercounseling merupakan layanan konseling yang dilakukan dengan bantuan media online (Bloom \& Walz, 2003). Cybercounseling memungkinkan konselor dan konseli untuk melakukan komunikasi tatap muka melalui layar monitor tanpa kehadiran fisik secara langsung, hal ini akan banyak menghemat jarak dan waktu (Harris \& Birnbaum, 2015; Maples \& Han, 2008). Dengan cybercounseling, konselor dapat memberikan layanan konseling di mana saja dan kapan saja sesuai kesepakatan antara konselor dan konseli selama privasi tetap terjaga. Perkembangan teknologi sudah tidak asing lagi bagi siswa, yang mana mereka sudah akrab dengan media sosial, seperti Facebook, Twitter, Blog, Skype, dan E-mail membuat penulis memilih cybercounseling untuk meningkatkan keterbukaan diri siswa.

Penulis ingin mengembangkan cybercounseling menggunakan pendekatan yang spesifik, yakni pendekatan realita. Sejauh ini cybercounseling yang sudah dikembangkan masih menggunakan pendekatan yang umum (Murphy, MacFadden, \& Mitchell, 2008). Pendekatan cybercounseling yang spesifik akan memudahkan konselor dalam memberikan layanan konseling sesuai tahapan pendekatan yang digunakan. Sebagai upaya membantu konselor dalam mengimplementasikan layanan cybercounseling untuk meningkatkan keterbukaan diri siswa, perlu adanya sebuah buku panduan cybercounseling, agar konselor mampu menjalankan cybercounseling dengan efektif.

Tujuan penelitian ini untuk menghasilkan website dan buku panduan cybercounseling realita untuk meningkatkan keterbukaan diri siswa SMK yang berterima secara teoretis dan praktis. Website digunakan oleh siswa dan konselor untuk mengakses layanan cybercounseling. Buku panduan digunakan oleh konselor sebagai petunjuk teknis pelaksanaan cybercounseling realita.

\section{METODE}

Rancangan penelitian ini menggunakan penelitian dan pengembangan model Borg \& Gall yang telah dimodifikasi (Sukmadinata, 2012). Langkah pengembangan dilakukan dalam tiga tahap, yaitu: (1) studi pendahuluan, (2) pengembangan produk, dan (3) uji produk. Studi pendahuluan berisi tiga langkah, yaitu: (1) survei lapangan, (2) studi kepustakaan, dan (3) penyusunan produk awal atau draf model. Survei lapangan dilaksanakan untuk mengumpulkan data berkenaan dengan perencanaan dan pelaksanaan penelitian. Pengumpulan data awal dalam penelitian dilakukan dengan observasi, pelancaran angket, dan wawancara. Data yang dikumpulkan berkenaan dengan keterbukaan diri siswa dan kemampuan konselor dalam melakukan konseling. Studi kepustakaan dilakukan dengan mempelajari konsep-konsep atau teori-teori yang berhubungan dengan produk yang akan dikembangkan, terkait dengan cybercounseling, konseling realita, dan keterbukaan diri. Berdasarkan hasil dari survei lapangan dan studi kepustakaan, secara konseptual dan praktis serta didukung oleh penelitian-penelitian terdahulu, menunjukkan bahwa media yang tepat digunakan untuk meningkatkan keterbukaan diri siswa adalah konseling melalui media online. Berdasar hasil tersebut, maka draf model atau produk awal yang akan dikembangkan adalah website dan panduan cybercounseling.

Tahap pengembangan produk dilakukan dengan pembuatan website cybercounseling dan penyusunan panduan untuk melaksanakan konseling di dalamnya. Selain mengembangkan produk, peneliti menyusun sejumlah instrumen terkait dengan produk yang dikembangkan. Instrumen yang disusun yaitu instrumen evaluasi produk dalam bentuk format penilaian untuk mengetahui kelayakan produk, dan instrumen untuk mengetahui tingkat keefektifan produk yang telah dikembangkan.

Pada tahap uji produk, langkah yang dilaksanakan adalah penilaian ahli, uji kelompok kecil dan uji kelompok terbatas. Penilaian ahli dilakukan oleh dua orang ahli, yaitu ahli media untuk menguji keberterimaan visualisasi website cybercounseling dan buku panduan dan ahli Bimbingan dan Konseling (BK) untuk menguji keberterimaan isi/materi yang ada dalam buku panduan cybercounseling. Penetapan subjek validasi ahli didasarkan pada beberapa pertimbangan atau dipilih secara purposive sampling, hal ini dimaksudkan untuk mendapatkan subjek validasi yang tepat. Berdasarkan hasil penilaian ahli, selanjutnya dilakukan revisi dan dilaksanakan uji tahap kedua. Uji tahap kedua adalah uji kelompok kecil dilakukan oleh dua orang konselor SMKN "X" Malang. 
Selanjutnya dilakukan revisi dan diuji kembali melalui uji lapangan terbatas yang dilakukan oleh tiga siswa SMKN "X" Malang kelas X, yaitu: dua siswa dari kelas X Akomodasi Perhotelan 2 (Inisial H. I. dan I. S.) dan siswa siswa dari X Usaha Perjalanan Pariwisata 2 (Inisial H. A.). Hasil uji lapangan terbatas dan balikan dari siswa setelah mengisi format penilaian digunakan sebagai bahan untuk menyusun produk akhir. Produk akhir yang dihasilkan adalah website dan panduan cybercounseling realita untuk meningkatkan keterbukaan diri siswa SMK beserta websitenya.

Jenis data yang digunakan berupa data angka (data kuantitatif) dan data non angka (data kualitatif). Data angka diperoleh dari format penilaian ahli terhadap produk yang dikembangkan. Data non angka merupakan data yang diperoleh dari kritik, saran, atau masukan secara umum tentang pengembangan website dan panduan cybercounseling dari uji ahli, uji kelompok kecil, dan uji lapangan terbatas. Instrumen yang digunakan dalam penelitian ini ada dua, yaitu instrumen evaluasi produk dalam bentuk format penilaian untuk mengetahui kelayakan produk, dan instrumen untuk mengetahui tingkat keefektifan produk yang telah dikembangkan. Teknik analisa data untuk mengukur kelayakan dari produk website dan panduan cybercounseling menggunakan analisis statistik deskriptif. Rumus yang digunakan untuk menghitung rata-rata tiap aspek penilaian adalah sebagai berikut:

$$
x=\frac{\sum x}{n}
$$

\section{Keterangan}

$\mathrm{x}$ : rata-rata

$\sum \mathrm{x}$ : jumlah penilaian

$\mathrm{n}$ : jumlah soal

Setelah dihitung, rata-rata hasil penilaian diklasifikasikan menjadi lima kategori yaitu: $1=$ tidak tepat/tidak jelas/tidak mudah/tidak menarik/tidak berguna; $2=$ kurang tepat/kurang jelas/kurang mudah/kurang menarik/kurang berguna; 3 = tepat/jelas/mudah/menarik/berguna; 4 = sangat tepat/ sangat jelas/sangat mudah/sangat menarik/sangat berguna. Dari hasil rata-rata klasifikasi penilaian ahli, dicari nilai rata-rata total keseluruhan, kemudian diambil kesimpulan mengenai produk yang diujikan. Klasifikasi penilaian rata-rata total keseluruhan dibagi menjadi empat kategori yang disajikan pada tabel 1 .

Keefektifan produk dianalisa menggunakan Paired Sample t-test dengan bantuan program SPSS IBM Statistic 20.0. Data yang dihitung menggunakan Paired Sample t-test merupakan data berpasangan. Uji t dilakukan apabila data yang diperoleh berdistribusi normal (statistik parametrik). Apabila data yang diperoleh tidak berdistribusi normal maka digunakan Wilcoxon Signed Ranks Test (statistik nonparametrik). Cara untuk melihat data dalam distribusi normal atau tidak normal bisa dilakukan melalui uji normalitas. Pengujian hipotesis ini menggunakan ketentuan apabila probabilitas $(\mathrm{p})>0,05$ maka $\mathrm{H}_{0}$ diterima dan apabila probabilitas $(\mathrm{p})<0,05$ maka $\mathrm{H}_{0}$ ditolak.

Data-data yang bersifat non angka atau kualitatif yaitu berupa saran, kritik, atau masukan dari para ahli, dan konselor akan dianalisis dengan cara menyusun dan mengelompokkan data yang ada, sehingga memberikan gambaran yang jelas terhadap aspek yang dinilai.

Tabel 1 Kriteria Rata-rata Total Keseluruhan Penilaian

\begin{tabular}{ccc}
\hline $\begin{array}{c}\text { Rerata Total } \\
\text { Keseluruhan }\end{array}$ & Persentase & Interpretasi \\
\hline $0-1$ & $0-25 \%$ & Sangat Tidak Layak \\
$1,01-2$ & $26-50 \%$ & Kurang Layak \\
$2,01-3$ & $51-75 \%$ & Cukup Layak \\
$3,01-4$ & $76-100 \%$ & Layak \\
\hline
\end{tabular}




\section{HASIL}

Proses penelitian dan pengembangan serta uji coba menghasilkan produk berupa website dan panduan cybercounseling realita untuk meningkatkan keterbukaan diri siswa SMK. Website diperuntukkan siswa dan konselor, sedangkan panduan ditujukan untuk konselor. Serangkaian tahap uji coba untuk menilai keberterimaan desain awal produk baik secara teoritis dan praktis, serta uji efektifitas dilakukan untuk mendapatkan produk akhir berupa website dan panduannya.

Berdasarkan hasil perhitungan penilaian ahli materi BK secara keseluruhan yang mencakup aspek ketepatan, kegunaan, kemudahan, dan kejelasan. Diperoleh nilai rata-rata 3,25. Dengan demikian, ahli materi BK menyatakan bahwa buku panduan yang dikembangkan termasuk kategori "layak". Selain data angka, penilaian ahli materi juga menghasilkan data non angka. Data non angka dalam bentuk saran dari ahli materi BK terkait dengan panduan yang dikembangkan, yaitu: (1) tahun pada sampul; (2) kata "tarik menarik" yang kurang tepat; dan (3) judul langkah dan isi pada tahap want serta do yang kurang relevan.

Selanjutnya, hasil perhitungan rata-rata keseluruhan terhadap website yang mencakup aspek ketepatan, kegunaan, kemudahan, kemenarikan, dan kejelasan, diperoleh nilai rata-rata 3,5. Nilai 3,5 dalam skala 0-4 termasuk dalam kategori layak. Hasil perhitungan penilaian ahli media terhadap panduan secara keseluruhan yang mencakup aspek ketepatan, kemudahan, kemenarikan, dan kegunaan, diperoleh nilai rata-rata 3,5. Nilai 3,5 dalam skala 0-4 termasuk dalam kategori layak. Dengan demikian ahli media menyatakan bahwa panduan dan website yang dikembangkan termasuk kategori "layak". Selain data angka, penilaian dari ahli media juga menghasilkan data non angka. Ahli media tidak memberikan masukan pada website yang dikembangkan. Data non angka dalam bentuk saran dari penilaian ahli media terdapat masukan terkait dengan buku panduan, yaitu: "Desain ornamen dalam header dan footer terlalu dominan, sebaiknya diperkecil (disederhanakan)".

Berkaitan dengan uji kelompok kecil, hasil perhitungan rata-rata keseluruhan terhadap panduan yang mencakup aspek ketepatan, kegunaan, kemudahan, kemenarikan, dan kejelasan, diperoleh nilai rata-rata 3,7. Nilai 3,7 dalam skala 0-4 termasuk dalam kategori layak. Sedangkan hasil perhitungan rata-rata keseluruhan terhadap website yang mencakup aspek ketepatan, kegunaan, kemudahan, kemenarikan, dan kejelasan, diperoleh nilai rata-rata 3,7. Nilai 3,7 dalam skala 0-4 termasuk dalam kategori layak. Dengan demikian konselor menyatakan bahwa panduan dan website yang dikembangkan termasuk kategori "layak". Selain data angka, dalam uji kelompok kecil terdapat beberapa saran perbaikan dari kedua konselor terkait dengan buku panduan, yaitu: (1) mohon ditambah hal-hal yang perlu diperhatikan dan batasan penggunaan cybercounseling, mungkin dengan diberi petunjuk umum dan khusus; (2) tambahkan catatan pada prosedur pengoperasian website jika konselor sudah memiliki/belum memiliki akun Skype; (3) sampul dibuat lebih menarik (ada ikon yang mewakili cybercounseling); dan (4) ukuran huruf diperbesar. Tampilan akhir sampul buku panduan disajikan pada gambar 1 .

Uji ahli pada konselor menghasilkan saran perbaikan website, dengan rincian sebagai berikut: (1) perbaiki kata sambutan pada beranda agar lebih menarik; (2) tambahkan form kontrak konseling pada menu pilih konselor; (3) tambahkan kata yang menyatakan kontrak pada menu etika konseling; dan (4) tambahkan fasilitas rekaman konseling; (5) tambahkan tata krama konseli ketika cybercounseling; (6) tambahkan jadwal cybercounseling; (7) lebih baik website diformulasikan agar bisa dibuka dengan Tablet PC/telepon seluler cerdas, dan (8) tambahkan form catatan rekaman konseling pada website.

Hasil uji coba yang terakhir adalah uji lapangan terbatas (siswa). Dari hasil perhitungan ratarata keseluruhan terhadap website yang mencakup aspek kejelasan, kemudahan, kemenarikan, dan kegunaan oleh uji kelompok kecil, diperoleh nilai rata-rata 3,45. Dengan demikian siswa dalam uji lapangan terbatas menyatakan bahwa website yang dikembangkan termasuk kategori "layak". Hasil akhir tampilan web disajikan pada gambar 2. Selain itu, dalam uji lapangan terbatas dilakukan uji keefektifan produk yang dikembangkan dengan menggunakan Paired t-test. Hasil pretest dan posttest ketiga siswa setelah dianalisis dengan paired $t$-test menunjukkan nilai probabilitasnya atau 


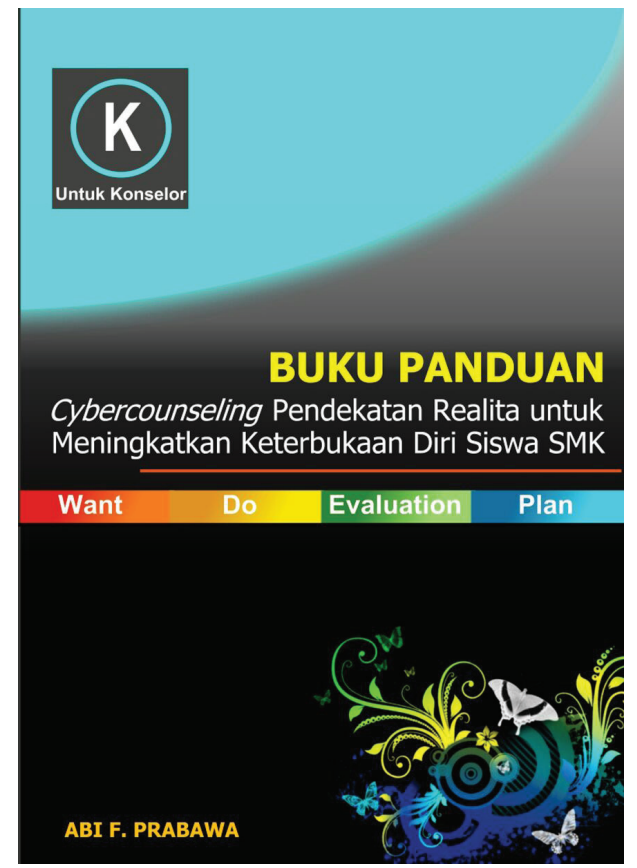

Gambar 1 Sampul Buku Panduan Cybercounseling Realita untuk Meningkatkan Keterbukaan Diri Siswa SMK

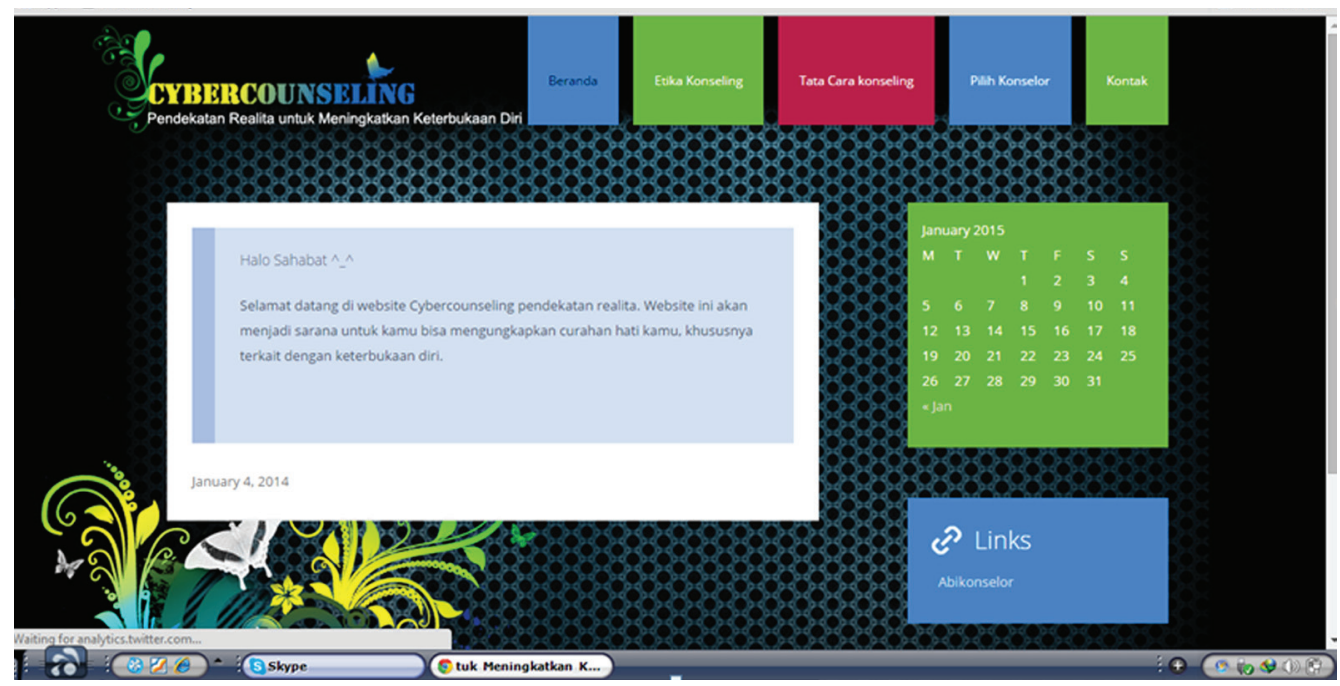

Gambar 2 Tampilan Website Cybercounseling

$p$-value adalah 0,024. Artinya, jika nilai probabilitas $(0,024)<0,05$ maka $\mathrm{H}_{0}$ ditolak dan $\mathrm{H}_{1}$ diterima, sehingga konseling realita menggunakan delivery system berupa website cybercounseling efektif meningkatkan keterbukaan diri siswa.

\section{PEMBAHASAN}

Melalui proses tahap uji kelayakan website dan panduan, terdapat beberapa revisi pada produk awal yang dikembangkan peneliti. Pada tahap pertama dilakukan penilaian ahli, dengan meminta bantuan kepada ahli media dan ahli BK. Website yang dikembangkan juga dinilai oleh ahli media dan konselor (uji kelompok kecil). Berdasarkan penilaian ahli media dan uji kelompok kecil, website dinyatakan layak digunakan karena telah memenuhi kriteria ketepatan, kegunaan, kemenarikan, kemudahan, dan kejelasan. 
Setelah melalui beberapa proses penilaian, wujud dari website yang dikembangkan sebagai berikut: memiliki desain seperti tampilan Windows 8 , dan memiliki lima menu utama pada bagian kanan atas. Menu pertama adalah "beranda" yang berisi ucapan selamat datang, menu kedua adalah "etika konseling" yang berisi aturan dan tata krama dalam konseling, menu ketiga adalah "tata cara konseling" yang berisi petunjuk sederhana bagi konseli untuk melakukan konseling, menu keempat adalah "pilih konselor" yang berisi tombol untuk memilih konselor untuk konseling, dan menu kelima adalah "kontak" yang berisi profil pengembang website. Secara spesifik dalam etika konseling terdapat informasi jam layanan. Luasnya akses untuk mendapat layanan cybercounseling (K. D. Baker \& Ray, 2011), mengharuskan adanya jam layanan untuk memberikan batasan jam pelayanan konseling (K. R. Baker, 2013). Jam layanan yang diberikan adalah mulai jam 08.0023.00 WIB. Salah satu kelemahan cybercounseling adalah keikhlasan konselor untuk memberikan layanan secara nonformal. Maka agar proses cybercounseling berjalan lancar perlu ada jadwal layanan cybercounseling bagi konseli yang membutuhkan layanan di luar jam sekolah/nonformal. Selain itu, pada menu etika konseling juga terdapat informasi yang menyatakan bahwa, "Diwajibkan untuk berpakaian rapi, menjaga sikap, dan kesopanan ketika konseling bagi konseli dan konselor". Hal ini dimaksudkan agar konselor dan konseli tetap menjaga etika konseling meskipun secara fisik tidak bertemu langsung (Bloom, 1998; Frame, 1997).

Tahap uji kelayakan website selanjutnya dilakukan oleh siswa melalui uji lapangan terbatas. Tiga siswa yang menjadi subjek penelitian menyatakan nyaman untuk bercerita secara terbuka melalui cybercounseling dan mudah dalam mengoperasikan website. Selain itu, pada uji lapangan terbatas dilakukan uji keefektifan panduan. Hasil dari uji keefektifan yang dilakukan pada tiga siswa menunjukkan nilai probabilitas sebesar 0,024 (nilai probabilitas $<0,05$ ) sehingga $\mathrm{H}_{0}$ ditolak. $\mathrm{H}_{0}$ ditolak artinya, panduan cybercounseling efektif untuk meningkatkan keterbukaan diri siswa. Kecenderungan siswa untuk lebih terbuka bercerita melalui cybercounseling didukung dengan temuan terdahulu. Cybercounseling dinyatakan efektif dan berimbas positif pada implementasi hasil konseling oleh konseli (Glasheen, Shochet, \& Campbell, 2016).

Ahli media menyatakan panduan yang dikembangkan layak secara teoretis, karena panduan telah dikembangkan sesuai kriteria ketepatan, kemudahan, kemenarikan, dan kegunaan. Berdasarkan penilaian ahli media, wujud dari panduan ini sebagai berikut: sampul depan berwarna biru muda dan terdapat gambar telepon seluler serta headset pada pojok kanan bawah. Buku panduan berjudul "Buku Panduan Cybercounseling Realita untuk Meningkatkan Keterbukaan Diri Siswa SMK". Pada bagian dalam, lembar halaman didesain dengan menambahkan ornamen pada header dan footer agar pembaca tidak bosan. Pada header website terdapat logo cybercounseling realita sedangkan pada footer terdapat gambar vektor kupu-kupu, judul bab/sub bab, dan nomor halaman. Selain itu, untuk mempermudah konselor dalam mencari letak bab yang penting, panduan dilengkapi dengan pembatas. Terdapat tiga pembatas dalam buku panduan ini, pembatas pertama pada bagian landasan teori, pembatas kedua pada bagian prosedur pengoperasian website, dan yang ketiga pada pelaksanaan tahap konseling. Panduan juga ditulis dengan jenis huruf "Arial" untuk mempermudah pembaca dalam membaca isi panduan. Hal ini didasarkan pada pernyataan bahwa tampilan yang bagus adalah tampilan yang menggunakan layout, tampilan dan gambar yang menarik (Baloglu \& McCleary, 1999; Efendi, 2009; Tiwasing, Sahachaisaeree, \& Hapeshi, 2014; Weddel, 2009).

Pada tahap penilaian ahli selanjutnya, panduan dinilai oleh ahli BK. Penilaian ini dimaksudkan untuk menguji relevansi antara teori yang bermuatan konseling dengan isi dari panduan yang dikembangkan. Ahli BK menyatakan panduan layak secara teoretis karena telah memenuhi kriteria ketepatan, kejelasan, kemudahan, dan kegunaan. Berdasarkan penilaian ahli BK, isi dari panduan sebagai berikut: terdapat empat bab pada panduan, bab 1 pendahuluan, bab 2 landasan teori, bab 3 deskripsi produk, dan bab 4 petunjuk dan prosedur pelaksanaan cybercounseling. Dalam panduan ini secara spesifik menggunakan pendekatan Realita. Tahapan konseling Realita dalam buku panduan mencakup want (mengeksplorasi keinginan dan kebutuhan konseli), do (mengeksplorasi usaha yang sudah dilakukan), evaluation (mengevaluasi usaha untuk mencapai keinginan), dan plan (rencana baru untuk mencapai keinginan)(Wubbolding, 2013). Dengan adanya pendekatan yang 
spesifik dalam panduan yang dikembangkan akan mempermudah konselor dalam memberikan layanan cybercounseling. Hal ini sekaligus menjadi jawaban atas penelitian sebelumnya yang belum menyertakan pendekatan secara spesifik (Saroh, 2010).

Berdasarkan hasil revisi penilaian ahli, panduan diujikan kepada konselor melalui uji kelompok kecil. Hasil penilaian konselor dalam uji kelompok kecil menyatakan bahwa panduan layak untuk digunakan. Pada uji kelompok kecil buku panduan disempurnakan dengan menambahkan petunjuk umum dan petunjuk khusus sehingga konselor mengetahui fungsi dan kegunaan khusus dari buku panduan ini. Pada petunjuk khusus juga ditambahkan tata krama konseling. Tata krama konseling dimaksudkan agar konselor tetap menjaga performansi (sikap, pakaian, dan kesopanan) dalam memberikan layanan meskipun tidak bertemu secara langsung (Bloom, 1998; Frame, 1997). Selain itu, agar buku panduan mudah dibaca maka ukuran huruf diubah menjadi 12 poin. Hal ini didasarkan pada pernyataan bahwa tampilan yang bagus adalah tampilan yang menggunakan layout, tampilan dan gambar yang menarik (Baloglu \& McCleary, 1999; Efendi, 2009; Tiwasing et al., 2014; Weddel, 2009)

\section{SIMPULAN}

Pengembangan website dan panduan cybercounseling realita untuk meningkatkan keterbukaan diri siswa SMK telah berterima secara teoretis dan praktis. Hasil uji keefektifan produk menunjukkan produk efektif untuk meningkatkan keterbukaan diri siswa SMK. Semua layanan khas yang disediakan pada website dan panduan penggunaan website telah terbukti tepat, berguna, menarik, mudah, dan jelas untuk digunakan. Saran pemanfaatan produk ditujukan untuk: (1) konselor, agar menggunakan produk guna meningkatkan keterbukaan diri siswa, khususnya agar siswa lebih aktif di kelas. Dalam proses cybercounseling, konselor harus memastikan adanya koneksi internet yang kuat untuk mendukung kualitas video conference pada cybercounseling, dan gunakan layanan chat pada aplikasi Skype agar cybercounseling tetap berlangsung ketika sinyal internet lemah; (2) peneliti selanjutnya, diharapkan menguji keefektifan produk dalam uji lapangan terbatas menggunakan subjek yang lebih banyak dan bervariasi. Selain itu, peneliti selanjutnya diharapkan menambahkan beberapa fitur yang terintegrasi pada website, seperti database konselor yang dilengkapi dengan formulir rekaman konseling untuk mendukung akuntabilitas konselor, serta software perekam audiovisual sebagai sarana evaluasi proses cybercounseling.

\section{DAFTAR RUJUKAN}

Amedie, J. (2015). The Impact of Social Media on Society. Advanced Writing: Pop Culture Intersections. 2. Diambil dari https://scholarcommons.scu.edu/engl_176/2

Andari, A. (2015). Peningkatan Keterbukaan Diri (Self Disclosure) Melalui Konseling Kelompok dengan Pendekatan Person Centered pada Siswa Kelas VII SMP IT Abu Bakar Yogyakarta. Jurnal Riset Mahasiswa Bimbingan Dan Konseling, 4(2).

Asandi, Q., \& Rosyidi, H. (2010). Self-disclosure pada Remaja Pengguna Facebook. Jurnal Penelitian Psikologi, 1(1), 87-98.

Baker, K. D., \& Ray, M. (2011). Online Counseling: The Good, The Bad, and The Possibilities. Counselling Psychology Quarterly, 24(4), 341-346. https://doi.org/10.1080/09515070.2011.6 32875

Baker, K. R. (2013). Making Ethics Work: Manage Your Counseling Time. Drug Topics, (OCT). Diambil dari http://www.drugtopics.com/legal-compliance/making-ethics-work-manage-yourcounseling-time

Baloglu, S., \& McCleary, K. W. (1999). A Model of Destination Image Formation. Annals of Tourism Research, 26(4), 868-897. https://doi.org/10.1016/S0160-7383(99)00030-4

Barak, A., \& Gluck-Ofri, O. (2007). Degree and Reciprocity of Self-disclosure in Online Forums. CyberPsychology \& Behavior, 10(3), 407-417. 
Bloom, J. W. (1998). The Ethical Practice of Web Counseling. British Journal of Guidance and Counselling, 26(1), 53-59.

Bloom, J. W., \& Walz, G. R. (2003). Cybercounseling \& Cyberlearning: An Encore. ERIC.

Burdenski Jr, T. K. (2011). Extending Reality Therapy with Focusing: A Humanistic Road for The Choice Theory Total Behavior Car. International Journal of Choice Theory and Reality Therapy, 31(1), 14.

Dewanti, T. C., Widada, W., \& Triyono, T. (2016). Hubungan Antara Keterampilan Sosial dan Penggunaan Gadget Smartphone terhadap Prestasi Belajar Siswa SMA Negeri 9 Malang. Jurnal Kajian Bimbingan dan Konseling, 1(3), 126-131. https://doi.org/10.17977/um001v1i32016p126

Efendi, A. (2009). Beberapa Catatan tentang Buku Teks Pelajaran di Sekolah. Insania, 14(2), 320333.

Frame, M. W. (1997). The Ethics of Counseling via The Internet. The Family Journal, 5(4), $328-$ 330. https://doi.org/10.1177/1066480797054009

Gainau, M. B. (2009). Keterbukaan Diri (Self Disclosure) Siswa dalam Perspektif Budaya dan Implikasinya Bagi Konseling. Jurnal Ilmiah Widya Warta, 33(1), 95-112.

Glasheen, K. J., Shochet, I., \& Campbell, M. A. (2016). Online Counselling in Secondary Schools: Would Students Seek Help by This Medium? British Journal of Guidance and Counselling, 44(1), 108-122. https://doi.org/10.1080/03069885.2015.1017805

Glasser, W. (1999). Choice Theory: A new Psychology of Personal Freedom. HarperPerennial.

Grinter, R. E., Palen, L., \& Eldridge, M. (2006). Chatting with Teenagers: Considering The Place of Chat Technologies in Teen Life. ACM Transactions on Computer-Human Interaction, 13(4), 423-447. https://doi.org/10.1145/1188816.1188817

Harris, B., \& Birnbaum, R. (2015). Ethical and Legal Implications on The Use of Technology in Counselling. Clinical Social Work Journal, 43(2), 133-141. https://doi.org/10.1007/s10615014-0515-0

Jannah, R., Zen, E. F., \& Muslihati, M. (2016). Pengembangan Permainan Simulasi Keterbukaan Diri untuk Siswa SMP. Jurnal Kajian Bimbingan dan Konseling, 1(2), 74-78. https://doi. org/10.17977/um001v1i22016p074

Katayama, M. (1996). The Relationship between Self-esteem and Self-disclosure of Negative Information. Shinrigaku Kenkyu, 67(5), 351-358. https://doi.org/10.4992/jjpsy.67.351

Maples, M. F., \& Han, S. (2008). Cybercounseling in The United States and South Korea: Implications for Counseling College Students of the Millennial Generation and The Networked Generation. Journal of Counseling \& Development, 86(2), 178-183. https://doi. org/10.1002/j.1556-6678.2008.tb00495.x

Murphy, L., MacFadden, R., \& Mitchell, D. (2008). Cybercounseling Online: The Development of A University-Based Training Program for E-mail Counseling. Journal of Technology in Human Services, 26(2-4), 447-469. https://doi.org/10.1080/15228830802102081

Nehra, N. S., \& Rangnekar, S. (2017). Relationship Understanding Between Emotional Stability, Self-disclosure and Social Adjustment. Journal of Intercultural Communication Research, 46(6), 558-578. https://doi.org/10.1080/17475759.2017.1387165

Novalina, S. D. (2017). Efektivitas Konseling Realitas untuk Meningkatkan Penyesuaian Diri. Analitika, 7(2), 99-104.

Pinarti, P. (2010). Pengembangan Inventori Keterbukaan Diri (Self Disclosure) Sebagai Instrumen Layanan Bimbingan Pribadi bagi Siswa SMK Negeri 1 Malang. Universitas Negeri Malang.

Rachman, S. (2016). Peran Guru Bimbingan dan Konseling dalam Pengembangan Profesional Guru di Jawa Timur. In Seminar Nasional Bimbingan dan Konseling. 
Radjah, C. L. (2016). Keterampilan Konseling Berbasis Metakognisi. Jurnal Kajian Bimbingan dan Konseling, 1(3), 90-94. https://doi.org/10.17977/um001v1i32016p090

Saroh, S. (2010). Pengembangan Panduan Pelayanan Konseling Melalui Media Facebook. Universitas Negeri Malang.

Sastama, G. D., Muslim, M., \& Djannah, W. (2017). Keefektifan Homeroom untuk Meningkatkan Keterbukaan Diri Siswa SMP. Consilium: Jurnal Program Studi Bimbingan dan Konseling, $5(1), 17-24$.

Sukmadinata, N. S. (2012). Metode Penelitian. Bandung: PT Remaja Rosda Karya.

Swenson, L. P., \& Rose, A. J. (2009). Friends' Knowledge of Youth Internalizing and Externalizing Adjustment: Accuracy, Bias, and The Influences of Gender, Grade, Positive Friendship Quality, and Self-disclosure. Journal of Abnormal Child Psychology, 37(6), 887-901. https://doi. org/10.1007/s10802-009-9319-z

Tiwasing, W., Sahachaisaeree, N., \& Hapeshi, K. (2014). Design Goals and Attention Differentiations Among Target Groups: A Case of Toy Packaging Design Attracting Children and Parents' Purchasing Decision. Design Principles and Practices, 7(1), 29-43.

Weddel, K. S. (2009). How to Choose a Good ESL Textbook. Northern Colorado Professional Development Center, 1-14.

Wubbolding, R. E. (2013). Reality Therapy for The 21st Century. Routledge. 